\title{
INFRASTUCTURAL BACKGROUND OF THE EVERYDAY PHYSICAL EDUCATION IN HUNGARIAN HIGH SCHOOLS
}

\author{
Henrietta Varga Szépné ${ }^{1}$ - Éva Katona ${ }^{2}$ - Dénes Páll ${ }^{3}$ - Ildikó Balatoni ${ }^{4}$ \\ $1,2,3,4$ University of Debrecen \\ ${ }^{1}$ hvarga@med.unideb.hu, ${ }^{2}$ katona.eva@gmail.com, \\ ${ }^{3}$ pall.denes@med.unideb.hu, ${ }^{4}$ balatoni@med.unideb.hu
}

\begin{abstract}
The Hungarian government is dedicated to supporting a healthy and sporty life-style, thus in the past years the number of initiatives directed to publicizing and promoting sports has increased considerably. The new Law of Public Education has put the emphasis on physical education and on organizing other sport events in schools. This led to the introduction, in a phasing-out manner, of the every-day physical education $(P E)$.

We were interested to know the infrastructural background of PE including the number and size of sports halls available for the students, how many classes can they accommodate at the same time, and when were they constructed. To this end a survey was conducted through telephone, contacting 200 high schools in 19 counties of Hungary. Do the schools have their own swimming pools, or do they conduct after-hours sports events. Data were analyzed using the EvaSys program.

The time of construction of the schools and their sports halls spans a wide range between the years 1530 and 2005. So do the number of students, between 150-1200. Nineteen of the schools have none, 67\% has one, and 18.8\% two sports halls. The size of these halls is also very variable, while in some schools it is only $25 \mathrm{~m}^{2}$, in others it can be as large as $2295 \mathrm{~m}^{2}$. In most cases the halls can accommodate one or two classes in parallel. Afternoon classes are held in $87 \%$ of the schools, and include basketball, fencing, and soccer, among others. However, only eleven of the interviewed high schools have swimming pools.

Research has called the attention to the fact that the exercise of Hungarian youth is too little. This puts the emphasis on the promotion of physical activity in schools. While there are large differences in the infrastructural background in the schools involved in the survey, they all strive to conduct after-hours sport events.
\end{abstract}

Keywords: youth, sport, high school, sport infrastructure (JEL Code: Z28)

\section{INTRODUCTION}

Physical activity is an essential part of a healthy lifestyle. The beneficial physiological effects of regular exercise are proven. Regular sports activity boosts heart and lung function, reduces blood lipid levels and blood pressure, it also reduces the risk of type 2 diabetes and the risk of developing cancer and aids in maintaining body weight (Oja et al. 2016). It contributes to healthy growth in childhood and adolescence and to the proper development of bone, muscle and nervous system (Pavlik et al. 2001; Pavlik, 2013). It also has a beneficial effect on mental capacity, and social interactions (Harsha, 1995).

There is a correlation between leisure time activities pursued by the youth and other elements of their lifestyle, such as their value system, health behavior and social situation (Pikó, 2005). Conversation and games are important elements in student extracurricular activities. Leisure time spent with family is typical of weekend and school break periods (Kinyó and Bús 2015).
The so-called "Hungarian Youth" large sample research that has been carried every four years since 2000 attempts to assess and track social and sociological characteristics, lifestyle, leisure time activities and cultural consumption habits of the 15-29 age groups (Perényi, 2014). The results of the 2016 survey - which involved 8000 young individuals between the ages of 15-29 - show that the ratio of those who perform regular extracurricular sports activities has not changed since 2012 , only nearly a third of the respondents do regular physical activities. The circle of friends fundamentally determines how leisure time is spent (Bauer et al. 2016).

The results of Hungarian time-budget surveys carried out at the millennium and in 2010 reflect that daily average time-budget devoted to active leisure time activities fell by nearly $30 \%$ during the period between the two surveys in the age groups between 15 and 19 years. While young people spent $13.7 \%$ of their leisure time on such activities in 2000 (44 minutes), in 2010 they only spent $10.0 \%$ (31 minutes). Nowadays, Hungarians in their twenties spend an average of 9 minutes a day with physical activity (Bittner, 2013). 
Researchers of the report entitled "Health and lifestyle of adolescents, 2010" came to the conclusion that gender and age significantly influences the regularity and length of physical activity (Németh and Költô 2011). The ratio of physically inactive students regarding the length of extracurricular sports activities is increasing in senior years of school. At the same time, younger age groups devote far greater time to passive leisure time activities than to sports (Pikó, 2002).

Physical activity, the need to care for the body, and inactive lifestyle are all present at the same time in today's society as there is no time for regular physical activity because of the accelerated lifestyle (Pikó and Keresztes 2007).

The Eurostat publication entitled „Youth in Europe” (2009) describes the characteristics of leisure time activities among the youth. Over $66 \%$ of the age group between 16 and 24 uses the internet daily and more than $80 \%$ uses the World Wide Web to communicate, search for information and to take advantage of online services. The survey also covered data on health, including obesity. The published data reflects that in Hungary $21.1 \%$ of age group between 15 and 24 and $39.6 \%$ of the age group between 25 and 34 are overweight. According to genders, $26.7 \%$ of men and $15.0 \%$ of women in the age group between 15 to 24 , while $52.4 \%$ of men and $26.8 \%$ of women in the age group between 25 to 34 have weight problems.

In seven-year-olds, every fourth girl and every fifth boy fell into the overweight or the obese category in Hungary in 2010 (Martos, 2010). According to a research in Eger, 25,8\% of nursery children (preschool age between 3-6 years), have obesity (Müller et al. 2017).

Objective quantification of changes in physical performance as a result of development in childhood raises a number of problems in certain preferred life stages (adolescences and youth). Surveys regarding fitness levels at a national scale have not been carried out in previous decades. Although Hungarian researchers carried out examinations regarding the physical development and strength of the age group from 3 to 18 in 1982-1984 and 2003-2006 (National Growth Survey), motor performance was not included in them (Karsai et al. 2013).

In spite of the fact that the health condition of the population is fundamentally determined by health behavior and childhood habits, as international data also supports, we do not possess such data. At the same time, the consequences of the lack of or reduced physical activity have been proven by a number of studies. This justified the introduction of everyday physical education in Hungary in 2012 and probably also led to the indirect assessment of youth fitness condition within the framework of a national survey. The National Unified Student Fitness Test (NETFIT ${ }^{\circledR}$ ) was developed for this purpose, as the compulsory method of Hungarian public education since the beginning of the 2014/2015 school year.

Assessment of national data pointed out (Kaj et al. 2017), that increased development is needed in 3 categories out of the examined 9, these are body mass index, body fat percentage and endurance shuttle run. Researchers found, as a result of surveys made in the 2015/16 school year, that school grades $\left(8^{\text {th }}\right.$ and $12^{\text {th }}$ grades) first leaving the ascending system of everyday physical education performed better than their peers who do not participate in everyday physical education yet, which is an important result at international level as well (Kaj et al. 2017).

It seems obvious, based on the above, that the everyday physical activity of young people is primarily determined by the physical education in schools. However, this not only requires an adequate number of lessons, namely a minimum of one physical education lesson per day, but also the presence of an infrastructural background.

As a result of previous research, we described sports facility availability at Hungarian sports schools (Balatoni et al. 2016). Our present study examines whether Hungarian high schools possess the infrastructure required for everyday physical education.

\section{MATERIALS AND METHODS}

Our research focused on high schools. The survey was done using a questionnaire based on a telephone interview. A total of 200 high schools were involved in 19 counties of Hungary and Budapest. The first group of our questions was aimed at the year the school gymnasiums were constructed, the number of gymnasiums and their capacities. These were followed by questions regarding afternoon sports activities and their lengths. The data were evaluated using the Evasys program (http://www.vsl.hu).

\section{RESULTS AND DISCUSSION}

Figure 1 - Percent of schools included in the survey in the counties of Hungary

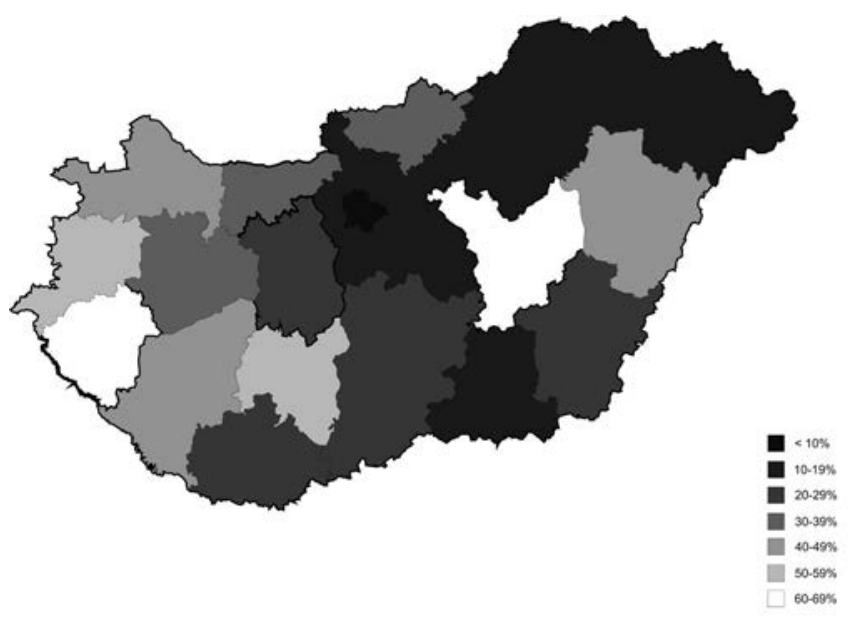

Source: Own compilation based on HCSO data

We compared the number of high schools in the counties of Hungary, using the database of the Hungarian Central Statistics Office (HCSO), to the number of questionnaires we completed. The percentage of involved institutions was represented by using a color scale (Figure 1). This clearly shows that $30-60 \%$ of the institutions were involved in $40 \%$ of the counties. Based on the above we consider our survey to be representative. 
The first question of the questionnaire was aimed at the date of construction of the specific school. This showed a period from 1530 to 2005, which is a very wide range. Most constructions were in the period between the Second World War and the change of regime.

Specific questions were also aimed at determining the date when the gymnasiums were constructed. The dates of constructions of schools and gymnasiums are presented in the same graph (Figure 2).

Figure 2 - Date of construction (school and gymnasium)

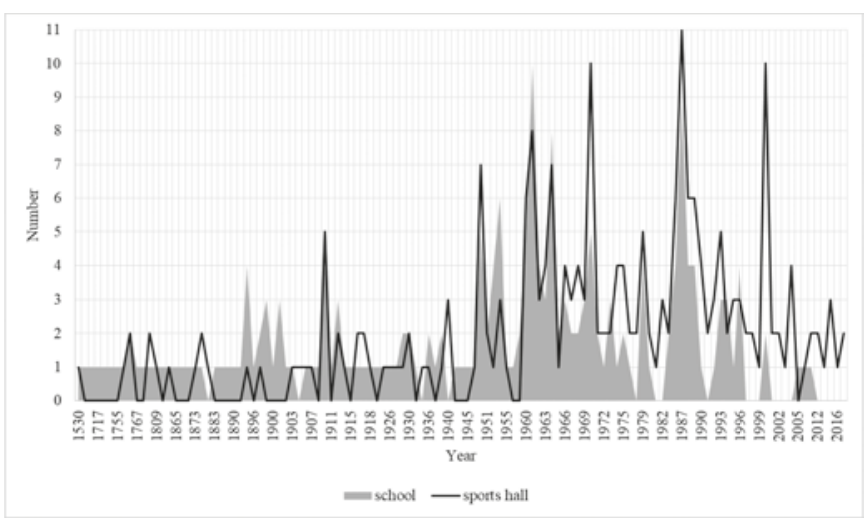

Source: Own compilation based on our questionnaires.

This also shows that the number of gymnasium constructions increased after the Second World War (Figure 2). In 115 of the cases the gymnasium was constructed in the same year as the school.

Figure 3 - Distribution of the number of schools with given number of students

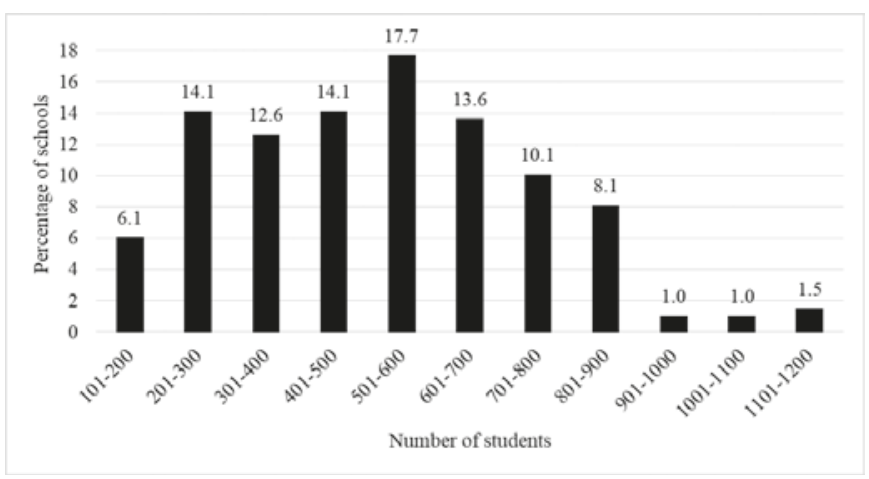

Source: Own compilation based on our questionnaires.

Student numbers in the schools involved in the survey also varied widely, between 100 and 1200 students, as depicted in Figure 3. In most schools, there are between 200 and 800 students.
Figure 4 - Distribution of the number of schools with given number of sports halls

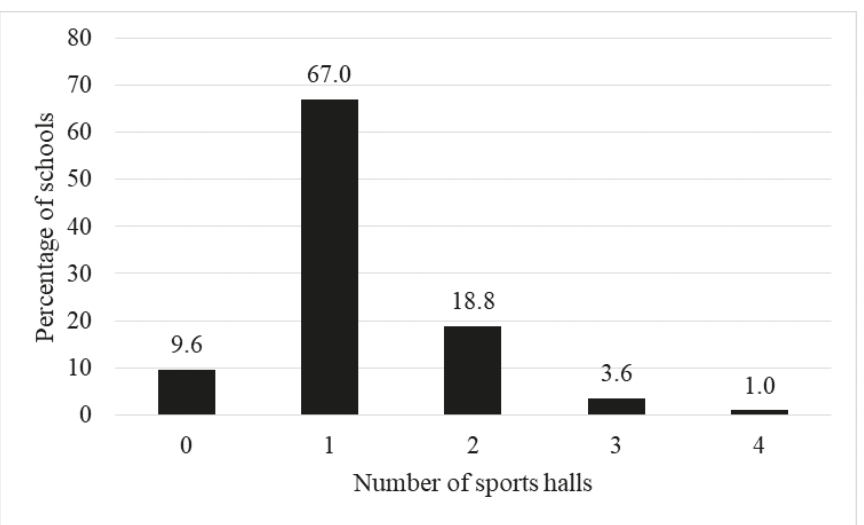

Source: Own compilation based on our questionnaires.

We also examined the number of gymnasiums per schools. As shown in Figure 4 in $67 \%$ of the cases there is 1, while in $19 \%$ of the cases there are 2 gymnasiums per school. High schools with more than 2 gymnasiums can be found in 11 counties. However, close to $10 \%$ of the schools do not have a gymnasium at all.

Figure 5 - Distribution of surface area of sports halls

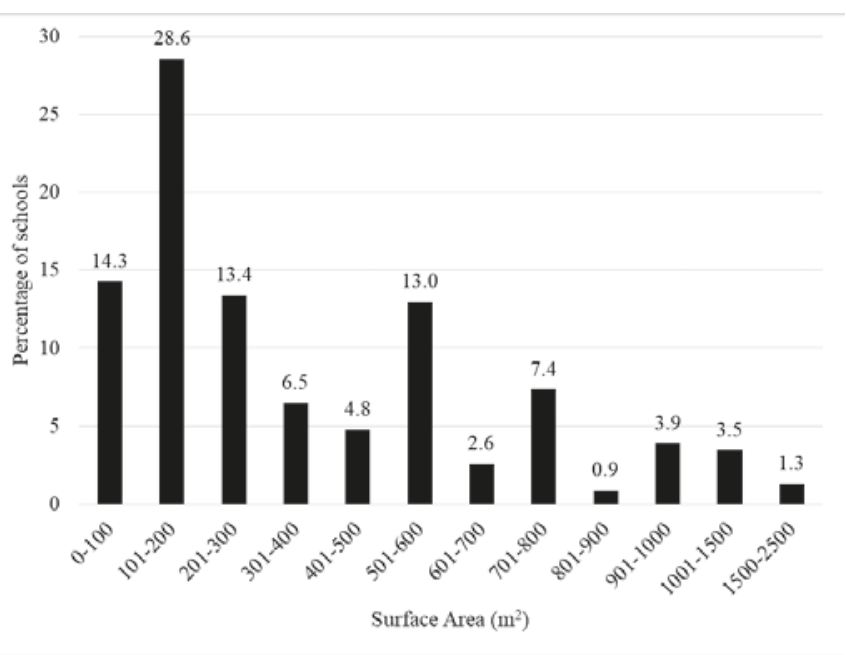

Source: Own compilation based on our questionnaires.

When examining the surface area of gymnasiums in $29 \%$ of the high schools one finds this between 100 and $200 \mathrm{~m}^{2} \cdot \mathrm{In}$ $40 \%$ of the cases the sizes are less than or equal to $100 \mathrm{~m}^{2}$, 201-300 $\mathrm{m}^{2}$, and 501-600 $\mathrm{m}^{2}$ (Figure 5). 
Figure 6 - Number of classes the sports halls can accommodate at a given time

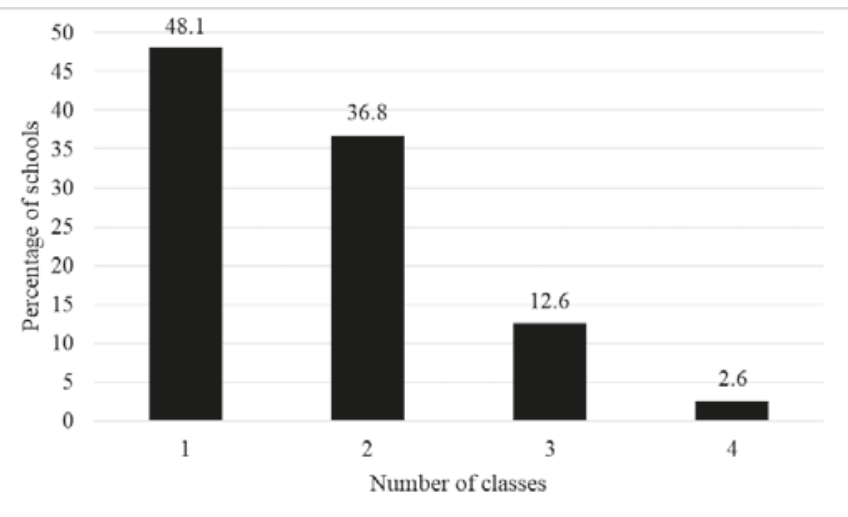

Source: Own compilation based on our questionnaires.

We were also interested in determining how many classes the gymnasiums can accommodate simultaneously. In $48 \%$ of the cases 1 , while in $37 \%$ of the cases they can accommodate 2 classes simultaneously (Figure 6).

\section{Figure 7 - The presence of a stand in the sports hall}

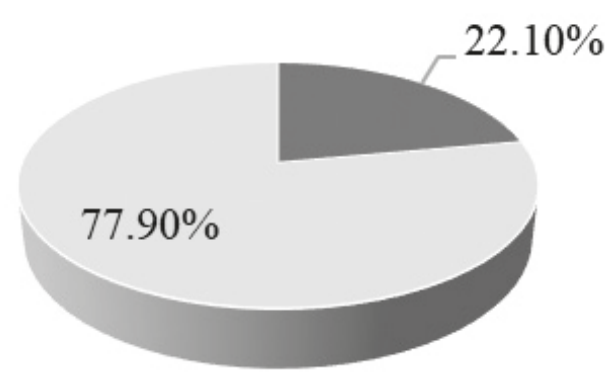

\section{- Yes No}

Source: Own compilation based on our questionnaires.

$22.1 \%$ of the gymnasiums have grandstands based on the responses we received (Figure 7).

Figure 8 - Number of schools with the given number of persons who can use the stand

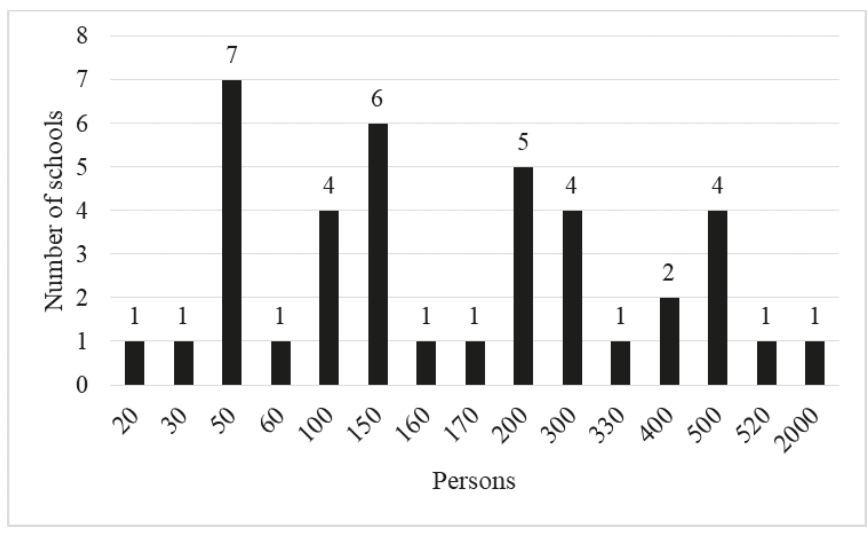

Source: Own compilation based on our questionnaires.
Their capacities typically vary from 50 to 500 spectators (Figure 8).

Figure 9 - The presence of a swimming pool in the surveyed schools

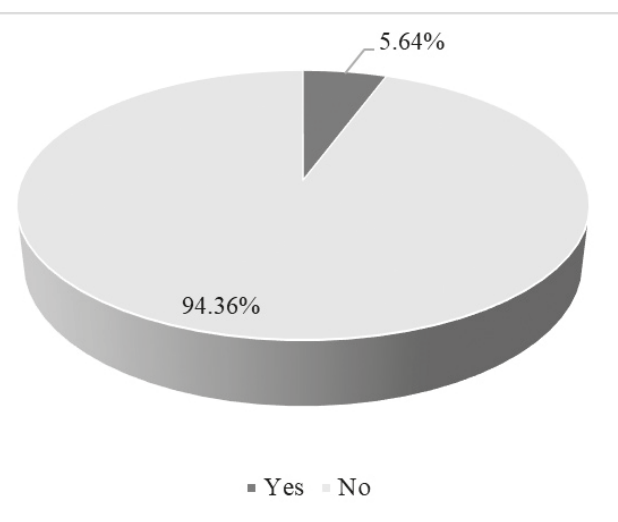

Source: Own compilation based on our questionnaires.

Only $5.5 \%$ of the schools have their own swimming pools (Figure 9).

Figure 10 - Length of the swimming pool

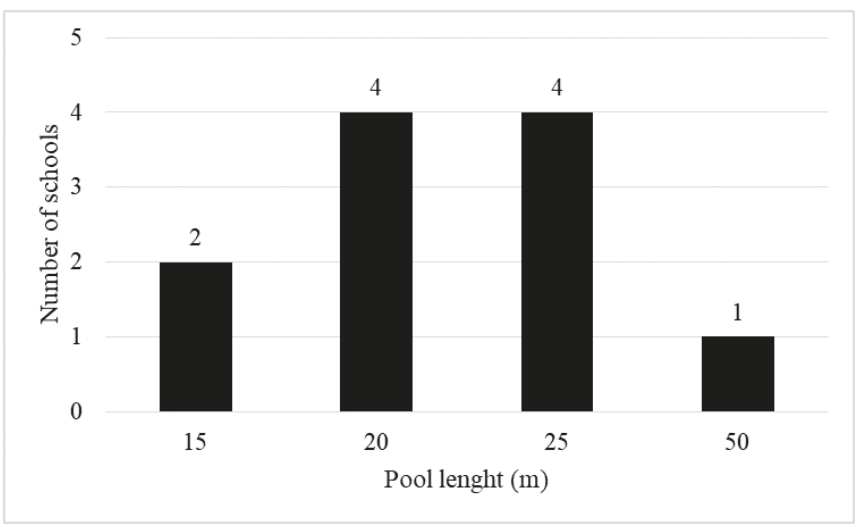

Source: Own compilation based on our questionnaires.

These are typically 20 or 25-meter-long swimming pools (Figure 10).

Figure 11 - Afterhours sports classes according to discipline

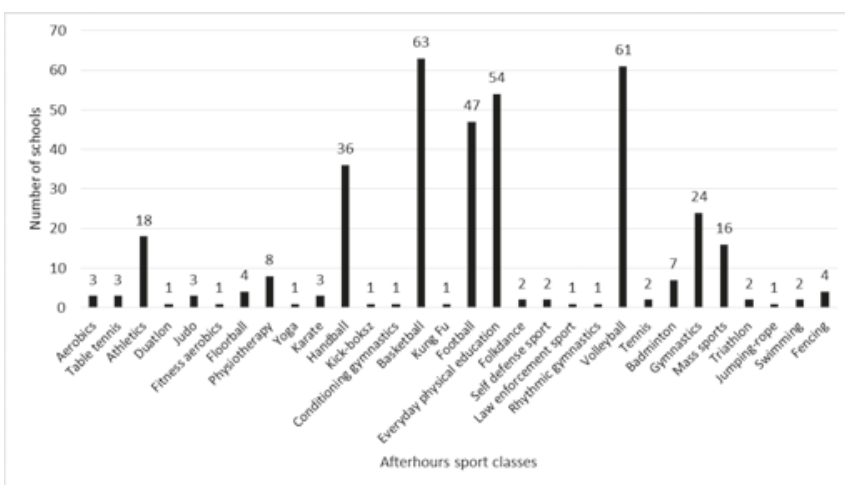

Source: Own compilation based on our questionnaires. 
The most common afternoon sports activity is basketball. This is followed by volleyball, general physical education, soccer and handball (Figure 11). It can be said that ball games lead among the most common afternoon sports activities.

\section{Figure 12 - Number of days in a week with afterhours sports classes}

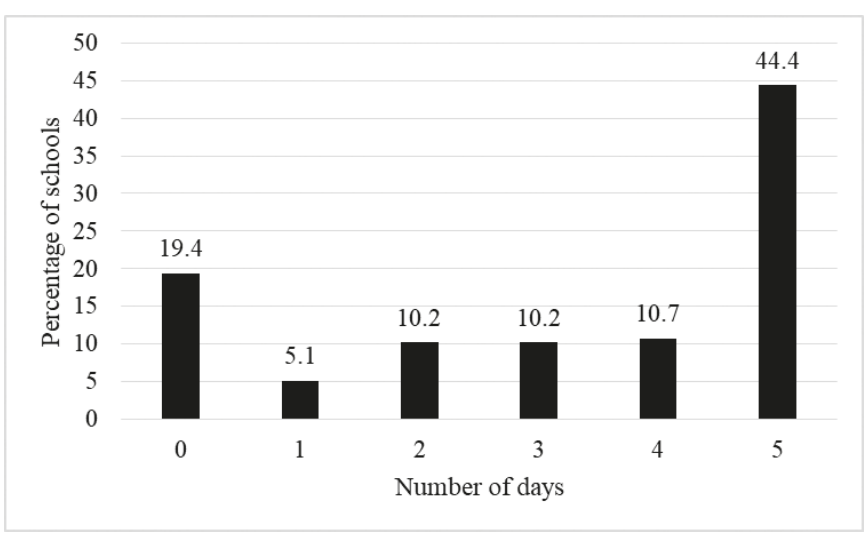

Source: Own compilation based on our questionnaires.

Due in part to the fact that two lessons per week can be replaced with certified sports activities at sports associations or organizations, only $44.4 \%$ of the schools hold some kind of afternoon sports activities every day (Figure 12). Unfortunately $19.4 \%$ of the schools does not hold afternoon sports trainings at all as they claim that the gymnasiums are required for everyday physical education lessons in the afternoons too, so there is no opportunity to accommodate other sports trainings.

\section{CONCLUSIONS}

A number of studies pointed out the role of youth sports in preserving health. As appropriate

infrastructure is also required to pursue adequate sports activities at school, a number of studies have examined the sports facility availability of local communities in general (Isgor and Powell, 2011; Todd, 2014; Abbott et al., 2014; Bezold et al., 2017;) and specifically of educational institutions (Judge et al., 2013; Patil and Metri, 2016).

All these studies pointed out that the built environment, whether it is the gymnasiums in schools or facilities around schools, contribute to increasing student physical activity. We believe that the development of sports facilities improves the sports conditions of all generations. Education for a sporty lifestyle must start in childhood and the everyday physical education introduced in an ascending system as part of the modification in the 2012 Act on Public Education can play a significant role in this.

Here we evaluated the data of 200 high schools in Hungary as part of our research. $18.8 \%$ of the schools have 2 gymnasiums, while $9.6 \%$ have no separate facility for accommodating physical education lessons. About $50 \%$ of the gymnasiums are suitable for accommodating 1, while $37 \%$ are suitable for accommodating 2 classes simultaneously. The most common sports for afternoon sports activities are ball games. Overall, it can be said that $90 \%$ of the high schools in Hungary have a gymnasium for accommodating everyday physical education. At the same time, the compulsory physical education lessons can only be provided in the afternoons in a significant number of cases, which occupies time and place from other, competitive sports activities. Therefore, it would be important by all means to improve the infrastructure for sports activities in Hungarian schools/high schools.

The gymnasium-construction program was initiated to achieve this, which aims to establish the conditions and opportunities for all students to pursue advanced physical education. Providing new and reconstructing of existing gymnasiums in educational institutions is necessary in order to achieve this (National Sports Strategy, 2007). The total budget devoted to gymnasium construction or large-scale renovation was 16 billion HUF in the period of 1995-2002 in schools managed by local governments, which is 8000 HUF per child. Sports life and access to sports facilities are least provided in settlements with less than 2500 inhabitants. $20 \%$ of the country's population lives in such settlements. At least 100 new gymnasiums should be constructed in the next 2 years within the facility development program serving both medium- and long-term objectives.

Our survey reflected the improved availability of facilities originating from the gymnasium development strategy of previous years. As of today $90 \%$ of Hungarian high schools have a gymnasium to provide everyday physical education. Most of these are suitable for performing physical education exercises, at the same time it must be emphasized that, on the one hand, swimming pools are present only in a few schools and, on the other hand, public education institutions with gymnasiums cannot always fulfill their tasks related to everyday physical education as part of the curriculum. As children represent the most important assets of our future therefore we must make all efforts to ensure conditions for their healthy lifestyle.

\section{ACKNOWLEDGEMENTS}

The research was supported by the Regional Development Fund within the framework of the GINOP-2.3.2-15-2016-00062 project entitled „Developing the quality of life in Eastern Hungary: Nutrition, performance biological and experimental biotechnology research and equipment development for preventing and treating human diseases".

\section{REFERENCES}

2011. évi CXC. törvény a nemzeti köznevelésről

65/2007. (VI. 27.) OGY határozat a Sport XXI. Nemzeti Sportstratégiáról http://mkogy.jogtar.hu/?page=show\&docid=a07h0065. OGY Approached 2016.

Abbott G, Backholer K, Peeters A, Thornton L, Crawford D, Ball K. (2014): Explaining educational disparities in adiposity: the role of neighborhood environments. Obesity (Silver Spring). 2014; 22(11):2413-9. 
Balatoni I, Kith N, Kosztin N, Csernoch L. (2016): The system of sports schools in respect with youth-training in Hungary. J. Educ. Health Sport. 2016; 6(13): 42-53.

Bauer B, Pillók P, Ruff T, Szabó A, Szanyi F. E, Székely L. (2016): Ezek a mai magyar fiatalok! Magyar Ifjúsági Kutatás 2016 Az ifjúságkutatás elsố eredményei. 2016. Magyar Ifjúság Kutatás 2017.

Bezold CP, Stark JH, Rundle A, Konty K, Day SE, Quinn J, Neckerman K, Roux AV. (2017): Relationship between Recreational Resources in the School Neighborhood and Changesin Fitness in New York City Public School Students. J Urban Health. 2017; 94(1):2029.

Bittner Z. (2013): A 15-29 éves korosztály tevékenység szerkezete az időmérleg-vizsgálatok tükrében. [Activity structure of the 1519-year- old generation in light of the time-scale surveys.] TÁMOP-4.2.3-12/1/KONV-2012-0016 Tudománykommunikáció a Z generációnak projekt keretében. TÁMOP Kiadó. Pécsi Tudományegyetem. 2013.

Eurostat (2009): Youth in Europe. A statistical portrait: Statistical books. Publications Office of the European Union. Luxembourg. 2009. from: http://pjp-eu.coe.int/documents/1017981/1668203/ YouthinEurope.pdf/40f42295-65e4-407b-8673-95e97026da4a Approached October 2016.

Harsha DW. (1995): The benefits of physical activity in childhood. Am J Med Sci, 1995. 310. 1. S109-13.

Isgor Z, Powell LM. (2011): Availability of commercial physical activity facilities and physical activity outside of school among high school students. J Phys Act Health. 2011; 8(5):707-15.

Judge LW1, Petersen JC, Bellar DM, Craig BW, Gilreath EL. (2013): CSCS certification and school enrollment impacts upon high school strength facilities, equipment, and safety. J Strength Cond Res. 2013; 27(9):2626-33.

Kaj M, Vass Z, Király A, Hernádi Á, Csányi T. (2017): A magyar 10-18 éves tanulók egészségközpontú fizikai fittségi állapota (2016); Kutatási jelentés a Nemzeti Egységes Tanulói Fittségi Teszt (NETFIT ${ }^{\circledR}$ ) 2015/2016. tanévi országos eredményeiről, Magyar Diáksport Szövetség. Budapest. 2017. from: http://www. mdsz.hu/wp-content/uploads/2017/01/1.sz_.mell\%C3\%A9klet_Kutata\%CC\%81si-jelente\%CC\%81s-2017.pdf Approached January 2017.

Karsai I, Kaj M, Csányi T, Ihász F, Marton O, Vass Z. (2013): Magyar 11-19 éves iskolások egészségközpontú fittségi állapotának keresztmetszeti vizsgálata. Első jelentés az Országos Reprezentatív Iskolai Fittség mérési Program eredményeiről. Magyar sporttudományi szemle. 2013. 14. 4: 9-18.
Kinyó L, Bús E. (2015): Az iskolai és iskolán kívüli társas tevékenységek jellemzôi és összefüggései az online adatgyújtésből származó háttéradatokkal 9012 éves diákok körében. Iskolakultúra. 2015. 25. 4.

Martos É. (2010): Folyamatosan nő az elhízott gyerekek száma. In: http://www.webbeteg.hu/cikkek/elhizas/10859/folyamatosanno-az-elhizott-gyerekek-szama

Müller A, Bíró M, Boda E, Herpainé LJ. (2017): Az óvodások testtömegének és sportolási szokásainak összefüggései egy egri kutatás tükrében. Acta Academiae Paedagogicae Agriensis Nova Series: Sectio Sport 44: pp. 191-203. 2017

Németh Á, Költő A. (2011): Serdülőkorú fiatalok egészsége és életmódja. Országos Gyermekegészségügyi Intézet. Budapest. 2011.

Oja P, Kelly P, Pedisic Z, Titze S, Bauman A, Foster C, Hamer M, Hillsdon M, Stamatakis E. (2016): Associations of specific types of sports and exercise with all-cause and cardiovascular-disease mortality: a cohort study of 80306 British adults. Br J Sports Med, 2016. 28.

Patil S, Metri VD. (2016): A survey of physical education and sports facilities and achievement in government and aided highschools at Koppal taluk. International Journal of Applied Research 2016; 2(2): 265-268.

Pavlik G, Olexo Z, Osvath P, Sidó Z, Frenkl R. (2001): Echocardiographic characteristics of male athletes of different age. Br J Sports Med, 2001. 35. 95-99.

Pavlik G. (2013): Élettan - Sportélettan. Medicina Könyvkiadó Zrt. Budapest. 2013.

Perényi Sz. (2014): A mozgás szabadsága! A szabadidősport társadalmi, gazdasági és egészségügyi megközelítései. Debrecen. 2014.

Pikó B, Keresztes N. (2007): Sport, lélek, egészség. Akadémia kiadó. Budapest. 2007.

Pikó B. (2002): Egészségtudatosság serdülőkorban. Akadémia kiadó. Budapest. 2002.

Pikó B. (2005): Középiskolás fiatalok szabadidő-struktúrája, értékattitúdjei és egészségmagatartása. Szociológiai Szemle. 2005. 2. 88-99.

Todd S. (2014): Bournemouth and Poole sports facilities strategy and action plan 2014-26. Bournemouth Borough Council. 2014. 